\title{
THE ADDITIONAL FUNCTIONS OF PORCH AND VAULT IN PANTAI BAHARI FISHING VILLAGE
}

\author{
Nurul Nadjmi*, Fadhillah Khairani Asrul** \\ *) Housing and Environmental Design, Architecture Study Program, Faculty of \\ Engineering, Hasanudin University \\ **)Undergraduate student, Architecture Study Program, Faculty of Engineering/ \\ Hasanudin University \\ E-mail: nurul_nadjmi@yahoo.com
}

\begin{abstract}
Pantai Bahari is one of the fishing villages in Bangkala Subdistrict, Jeneponto Regency, South Sulawesi Province, located in a coastal region where the community works as fishermen. The residents are still tightly holding their belief and respecting their customs, namely by living in traditional indigenous Bugis Makassar stilt house, with its philosophy of portraying the Underworld, the Middle world, and the Upper world over. The people also make some improvements over their house; one of them is against the function of porch and the space under the house (vault) that are perceived to depict 'the Underworld'. There are some factors influencing the emergence of additional functions of the porch and the vault. A single case study method was employed in this research involving Pantai Bahari fishing village. To analyse the data, both qualitative and quantitative methods were used. The results show several factors causing the additional functions of porch and vault, and the family structure, economic needs, the lack of areas to accommodate events, and the needs for mobility.
\end{abstract}

Keywords: additional functions of porch, additional functions of vault, fishing village, Pantai Bahari village

\section{INTRODUCTION}

According to Law number 27 year 2007 concerning Management of Coastal Areas and Small Islands, a coastal area is a transition between land and sea ecosystems affected by changes both at the land and at the sea. Pantai Bahari is one of fishing villages in Bangkala subdistricts, Jeneponto Regency, South Sulawesi Province and belongs into the coastal region where the residents work as fishermen. They still 
highly respect their customs as they live in traditional Bugis Makassar houses. Indeed, traditional architecture is a form of cultural property of Indonesia (Abidin, 1999). The diversity of traditional architectures is scattered along the archipelago and is very rich. Traditional architecture in each area also serves as the symbol of the cultural specificity of indigenous communities (Mattulada, 1988). As a form of culture, traditional architecture is developed from a single rule or agreement that is persistently preserved and maintained from one generation to generation (Mangunwijaya, 2009). The local community will obey the rules if they are perceived to meet their needs.

The formation of settlements in Pantai Bahari village is inseperable of the geochartal conditions and the surrounding environment, supported with daily activities of citizens as fishermen/sailors. The people will also search for seaweed during the rainy season and strong wind period, and then continue fishing in the dry season where the weather is nice and friendly. Nevertheless, the local community also demands positive changes in their settlements. The characteristics of Pantai Bahari fishing village with their traditional architecture are very interesting to research.

The typical traditional house of Bugis Makassar community is stilt house, as found in Pantai Bahari village. Today, there have been 266 houses and households living in the village. The common existing houses are rich in Bugis Makassar identity, with its philosophy of the Underworld, the Middle world, and the Upper world. As time goes by and the need for space within the house is rising, the people make some extension and improvement over their house. One of these extensions can be found in the function of porch and vault. The current issue is concerning how the additional functions of porch and vault are developed.

\section{Objectives}

The objective of the research is to observe the development of additional functions of porch and vault on the traditional Bugis Makassar stilt houses.

\section{THEORY AND METHOD}

\section{Literature Review}

\section{The Additional Functions of Porch}

Porch or terrace is transitional space between the outdoor and the indoor and vice versa, and is covered with one or two walls. It can be either at the front, next to, or behind the house; consequently, it leads to varying functions of those elements, 
depending on the position of the porch. The front porch serves as a service room or waiting area before the guests enter into the house. The side-porch could be a place to relax. A back porch is usually more closed, and thus could serve as a dining room, a place to perform activities or hobbies and to hold family gatherings. A porch also functions as providing air and light circulation. In traditional Bugis Makassar houses built in Pantai Bahari village, the porch is placed in front of the stilt house and comes in several types, including full porch, half porch, or no porch at all, as shown in Figure 1.

In its development, the functions become more diverse. Following the growing human needs, a porch serves not only as transitional space between the indoor and the outdoor areas; indeed, many people design their porch as multifunctional space. A porch can act as the area to welcome guests, and this has been in practice since a long time ago. It is apparent from the traditional home design. In traditional houses, a porch also serves as a meeting place where communications and social gatherings take place, as seen on traditional Bugis Makassar stilt houses called pa'daserang, with the same main function. In Pantai Bahari village, the porch varies in width, function, material and position

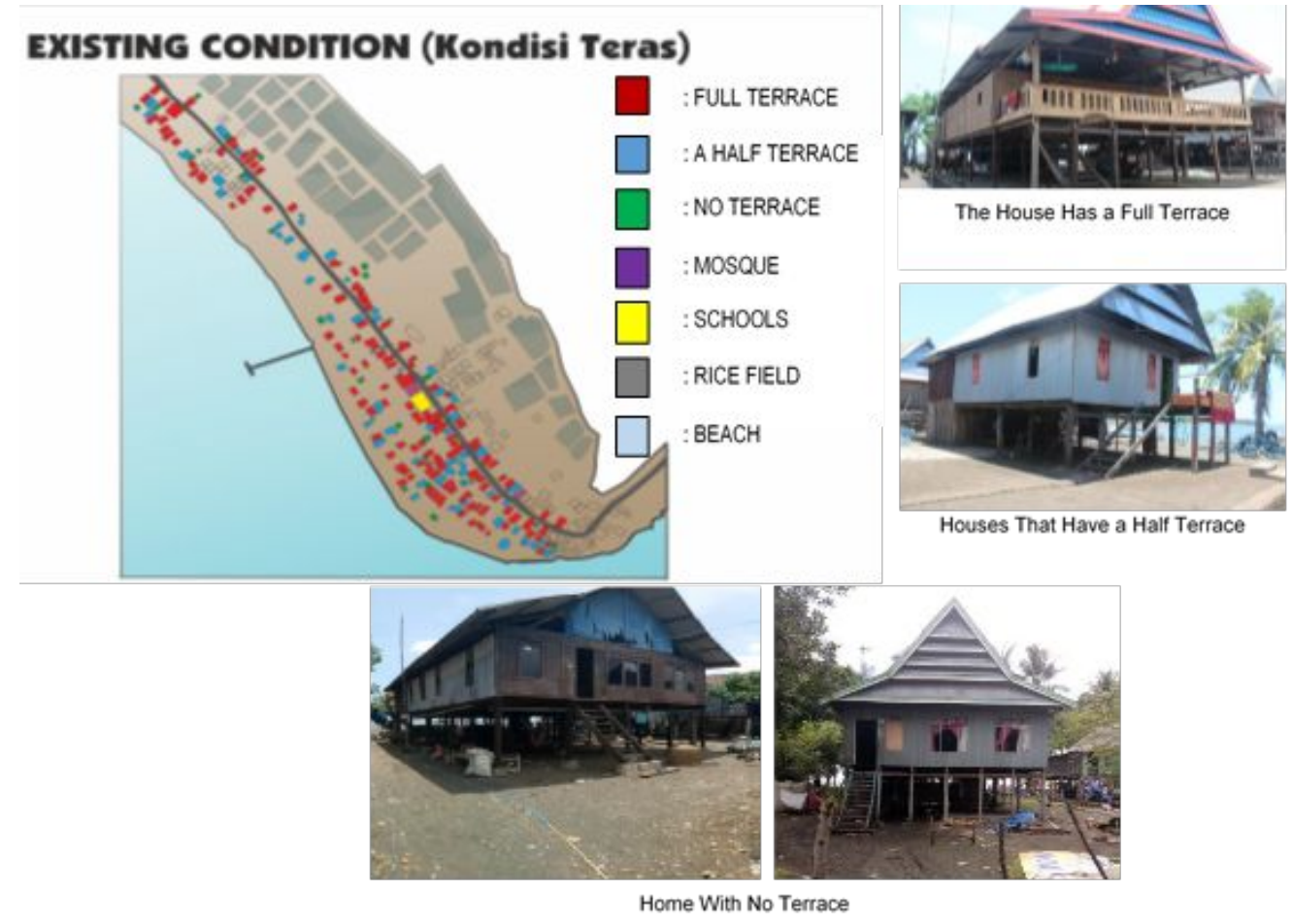

Figure 1. Different Types of Porchs in Houses at Pantai Bahari Fishing Village, Bangkala Subdistrict, Jeneponto Regency, South Sulawesi Province

Source: Site Survey, 2017 


\section{Additional Functions of Vault}

The vault is a space or hollow under the colonnaded or footed objects (such as beds, stilt houses). A stilt house is constructed of pillars; (http://www.artikata.com/arti335720-kolong.html). A stilt house contains beams and pillars, stages, and vault to store things and often as cages; moreover, the vault is sometimes used as a gathering spot (Ritalaksmitasari, 2013). Stilt houses in every region have their own characteristics based on types, the height of the stage, the roof shape, staircase, width, until the position of the house to the surrounding environment.

Based on the height of pillars, there are two types of stilt houses: a house having 1 meter or more pillar height, and a house with less than 1-meter pillar height. The function of the vault is adjusted to the height. The vault with pillars less than 1 meter are usually used for storage or enclosure. Meanwhile, the vault with more than 1 meter pillars height makes it possible for the vault to be used as shared space to socialize. Other activities in the vault are repairing fishing nets and gathering or sorting the fish/seaweed. It functions as a shared space to chat with family members or neighbors. To support the warm and friendly characters of Indonesian people, a house having a social space is perfect. The gathering activities in the vault might contain social value and stimulate creativity.

Notwithstanding, the stilt house is also designed to accommodate optimum absorption of rain water into the ground. The ground surface is not covered, allowing water to infiltrate into the ground, so as to minimize the possibility of flooding.

The residents in Pantai Bahari village often add and improve the functions of the vault. This is because the family structure has widened, the economic needs increase yet they have lack of land to accommodate the activities and needs for mobility space. The additional functions indeed have widely ranged (Figure 2).

\section{Method}

This research employed Phenomenology as the methodology. The data collected information about the houses of fishermen in particular those residing in the coastal area. The primary data to gather was concerning the porch and the vault from the physical size and changes in functions. The data collection techniques were field observations by taking photographs of the existing house conditions, interview with the local residents, and distributing questionnaires. The data from the questionnaire was needed to validate the results of purposive interview with the community leaders. Meanwhile, descriptive methodology was applied in analysing the data. 


\section{Existing Condition}

\section{Study Site Profile}

Bangkala sub district is situated at Jeneponto Regency, in South Sulawesi Province that is potential for seaweed cultivation because it has a long coastline of over $95 \mathrm{~km}$ with $749.79 \mathrm{~km} 2$ total area. One type of seaweed cultivated in Jeneponto Regency is Eucheuma Cottonii. This type of seaweed has a very high economic value. Meanwhile, Bangkala has $121.82 \mathrm{~km} 2$ area with total population of 46,932 inhabitants and 385/km2 density (Figure 3).

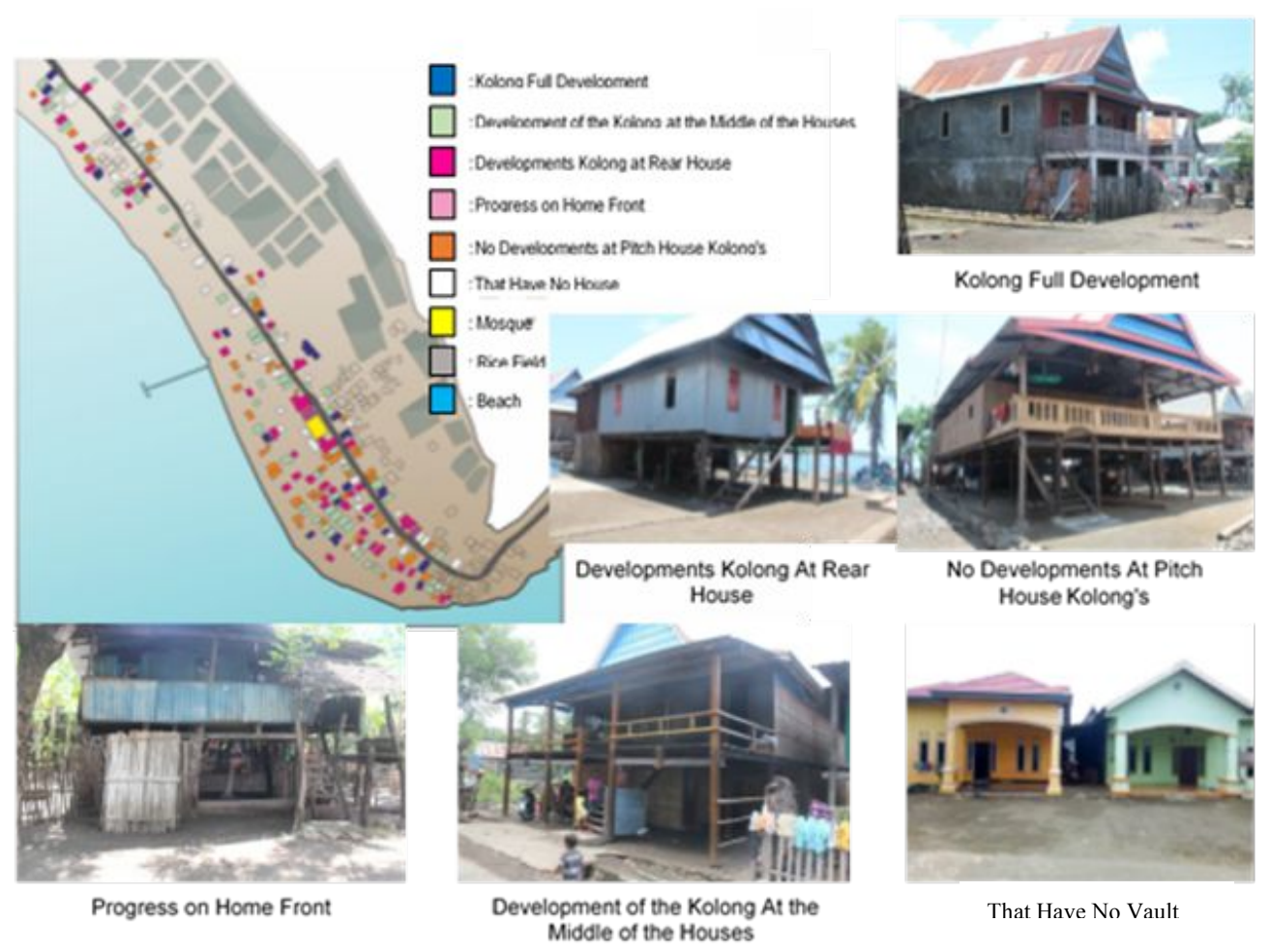

Figure 2. Exisiting Condition of Vaults at Pantai Bahari Fishing Village Source: Illustration and Site Survey, 2017 


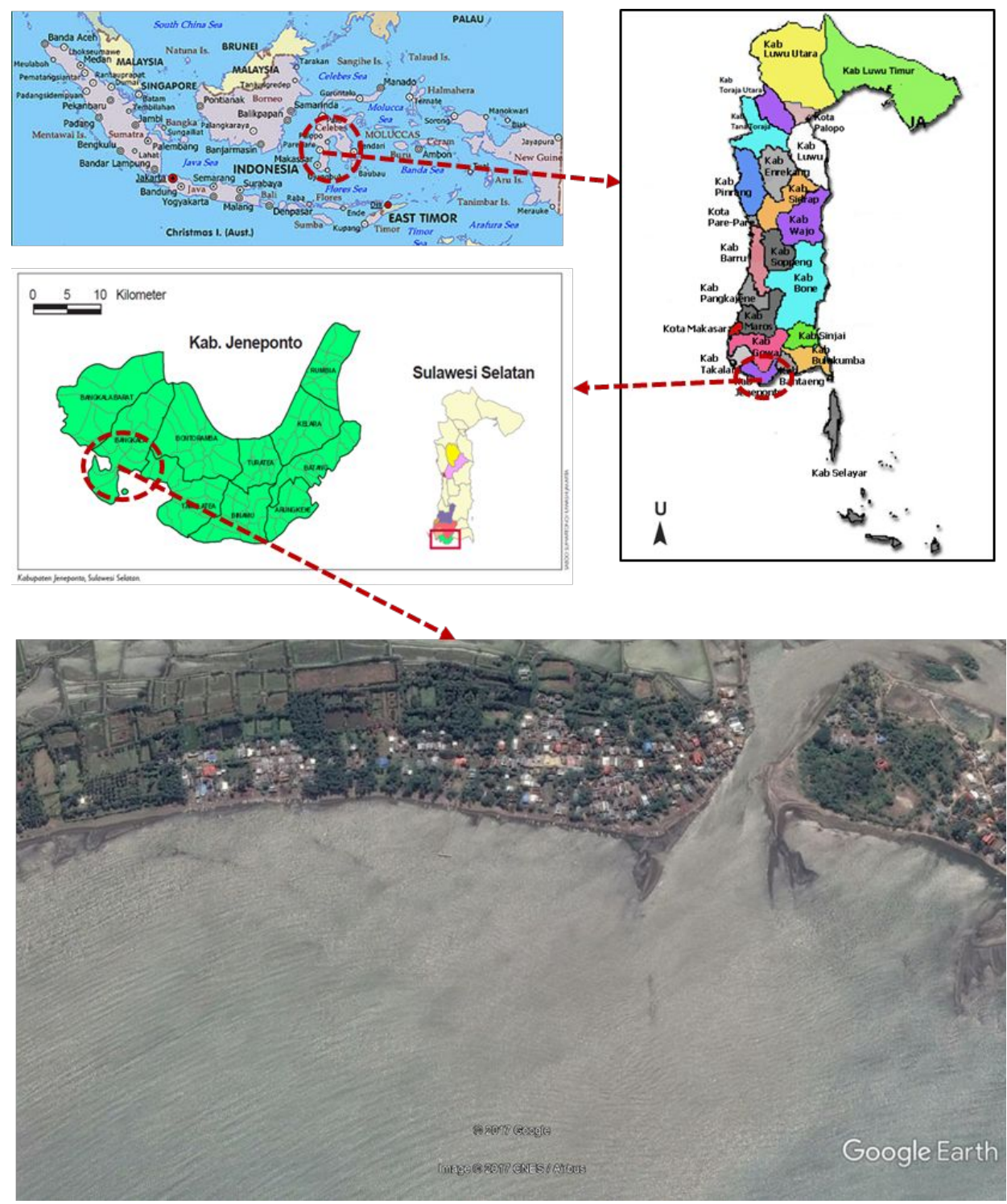

Figure 3. Site of Pantai Bahari Fishing Village, Bangkala, Jeneponto, South Sulawesi Province

Source: Author's Analysis from varying sources, 2017

\section{RESULTS \& DISCUSSION}

\section{The Additional Functions of Porch}

According to the data obtained, the types of porch found in Pantai Bahari fishing village can be seen in the following figure (Figure 4). 


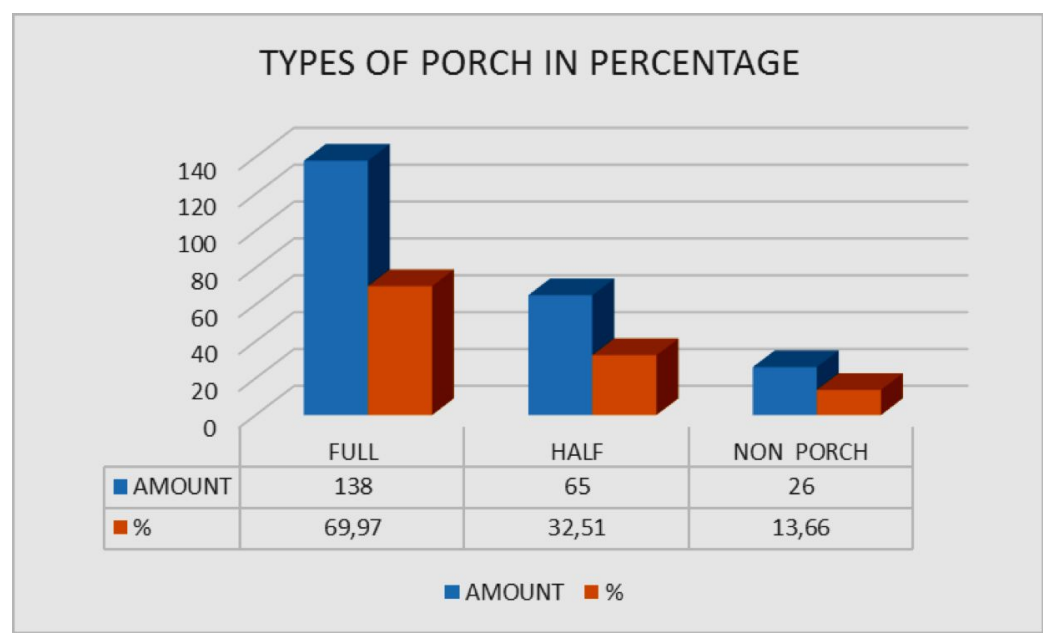

Figure 4. Types of Porch in Percentage Source: Author's Analysis, 2017

The full and half porch in the stilt houses found in the village is generally used to conduct numerous activities, namely relaxing, socializing, as well as keeping the vehicle and storing goods (Figure 5).

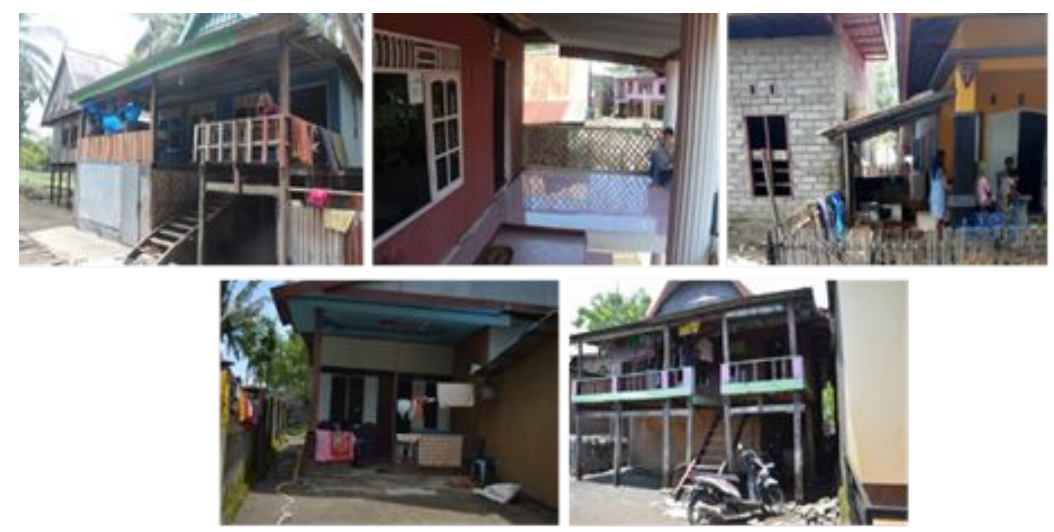

Figure 5. Various Activities on the Porch Source: Site Survey, 2017

\section{Additional Functions of Vault}

The data in Figure 6 shows the comparison of the additional functions of vault according to the position in the house. 


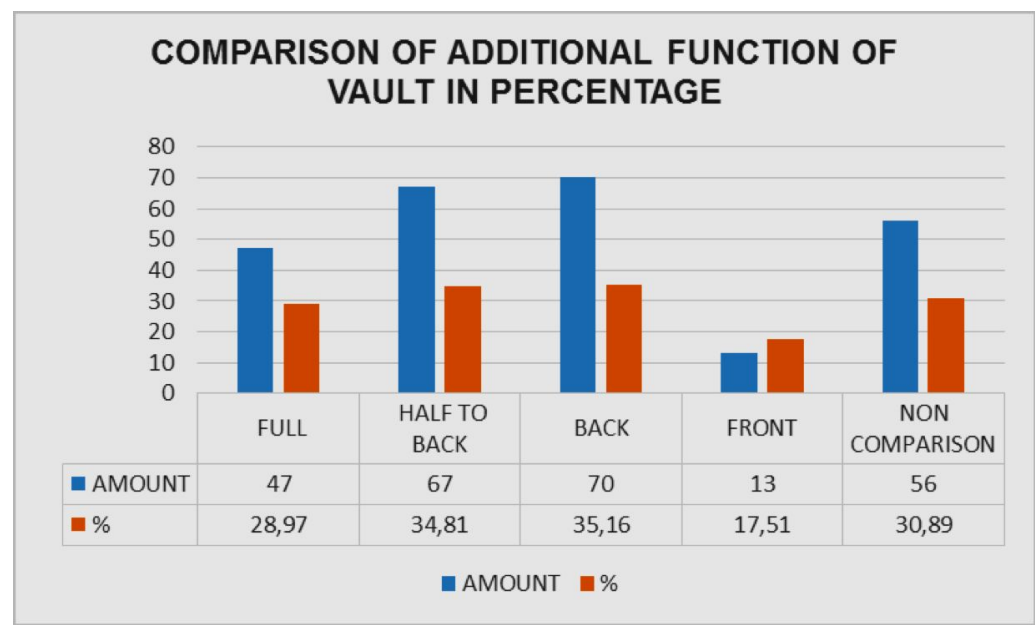

Figure 6. Comparison of Additional Functions of Vault in Percentage Source: Author's Analysis, 2017

The additional functions of vault are adjusted to the types of activities and height of the vault. The average vault height is $2 \mathrm{~m}$, with the maximum of $2.5 \mathrm{~m}$ and the minimum 1 . With such height, the vault could serve as a space to carry out various activities of the inhabitants. The activities that take place in the vault can be seen in figure 7 to 13 .

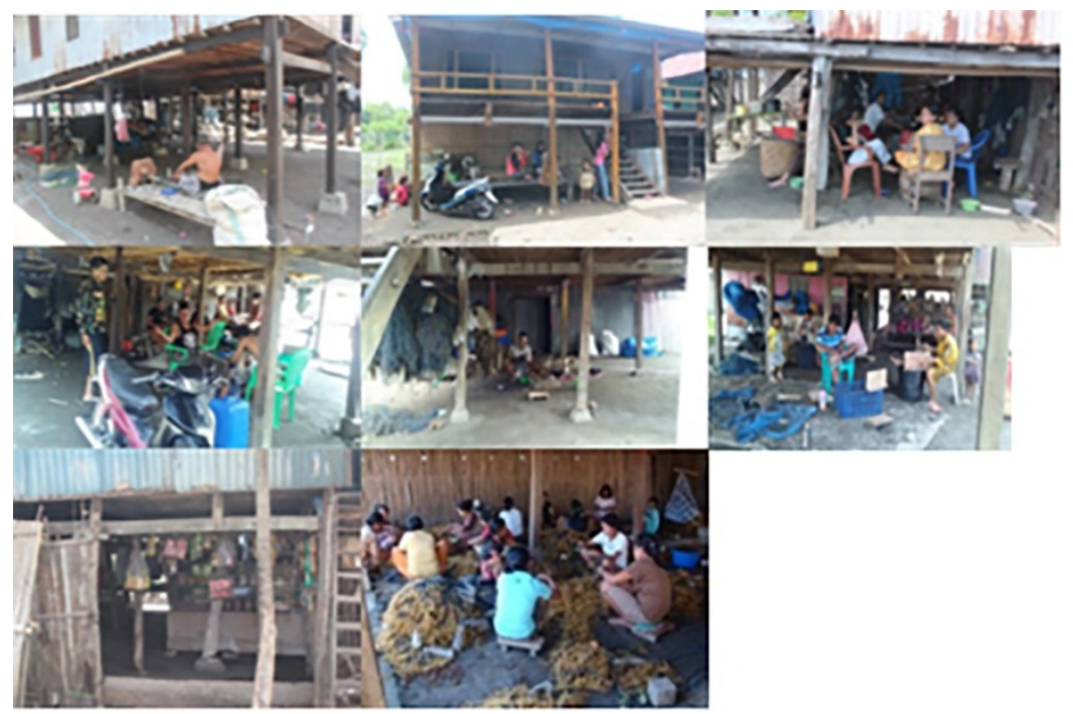

Figure 7. Various Activities Conducted at Kolong or Vault Source: Author Survey Results, 2017 


\section{The Development Pattern of Vault in Pantai Bahari Fishing Village}

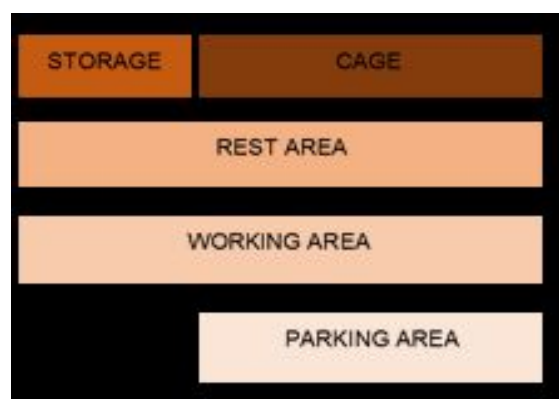

Figure 8. Additional Functions of Vault at Back with Wood/Bamboo Cover as Cage and Storage Area

Source: Author's Analysis, 2017

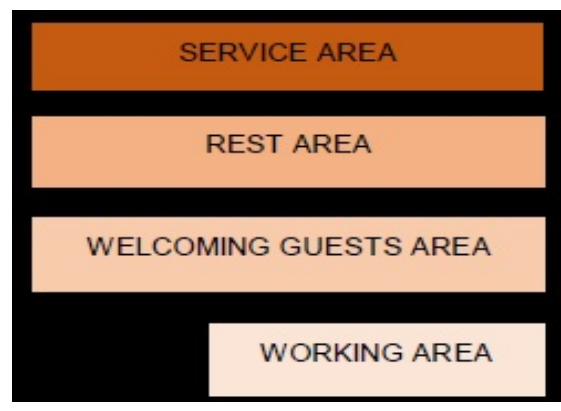

Figure 10. Additional Functions of Vault at Back with Wood/Bamboo Cover and Area for Service and Relaxing Source: Author's Analysis, 2017

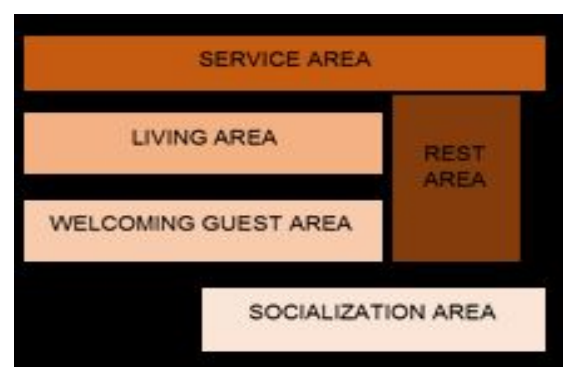

Figure 12. Extended Function of Vault at the Middle-Side with Brick Cover as an Area for Service, Relaxing, Welcoming Guests, and a Living Room Source: Author's Analysis, 2017

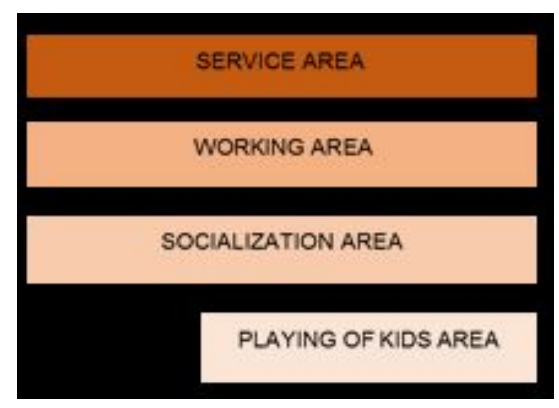

Figure 9. Additional Functions of Vault at Back with Wood/Bamboo Cover as Kitchen, Toilet, and Laundry Source: Author's Analysis, 2017

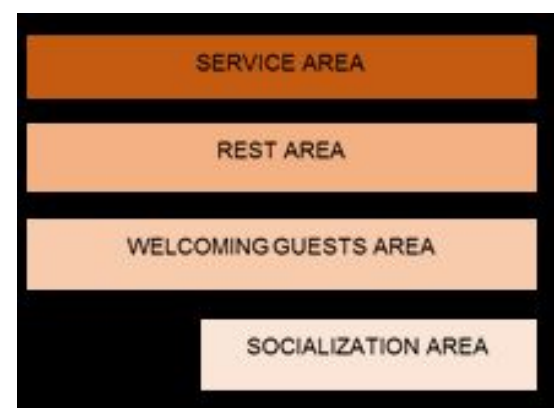

Figure 11. Additional Functions of Vault at Back with Wood/Bamboo Cover an Area for Service, Relaxing, and Welcoming Guests

Source: Author's Analysis, 2017

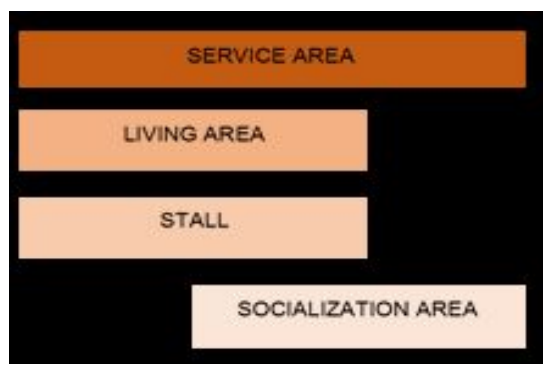

Figure 13. Extended Function of Vault at the Back-Front with Brick Cover as an Area for Service, Welcoming Guests, Living Room, and Stall Source: Author's Analysis, 2017 
The additional functions of vault at the stilt house in percentage can be seen in the following figure (Figure 14).

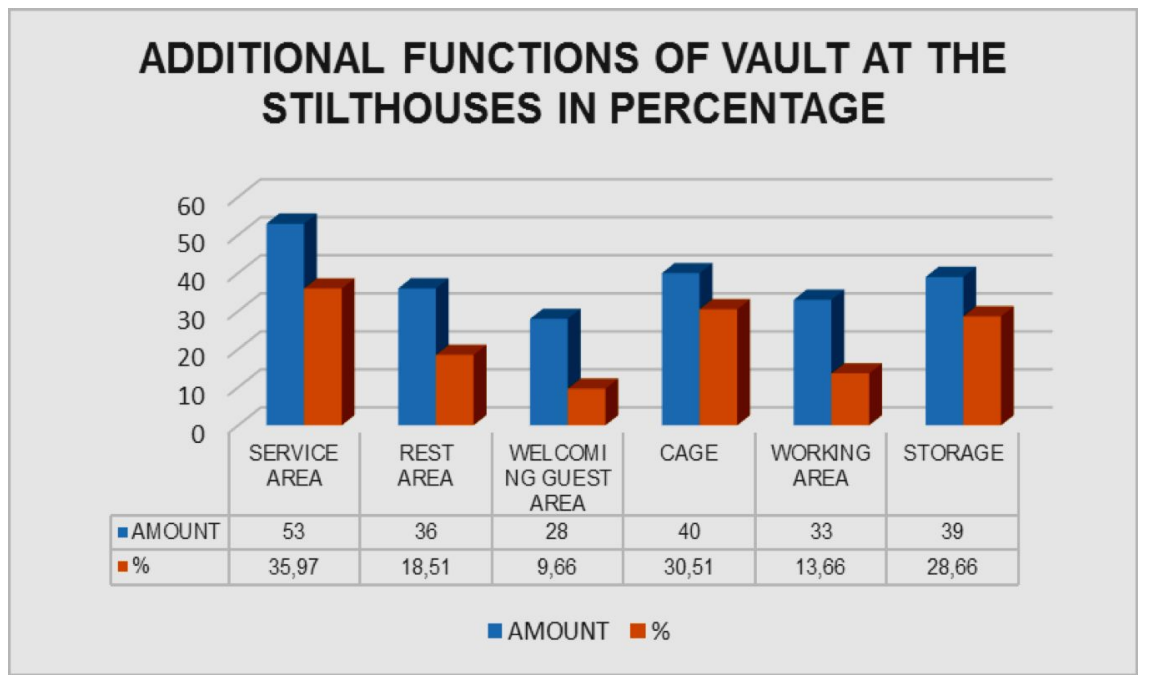

Figure 14. Additional Functions of Vault at the Stilthouses in Percentage Source: Author's Analysis, 2017

Based on the field survey, in addition to the description of illustration on the previous discussion, some supporting data were obtained concerning the vault cover. The materials used to cover the vault in Pantai Bahari fishing village are varying. The following figure shows the number of vaults with and without cover along with the materials used (Figure 15).

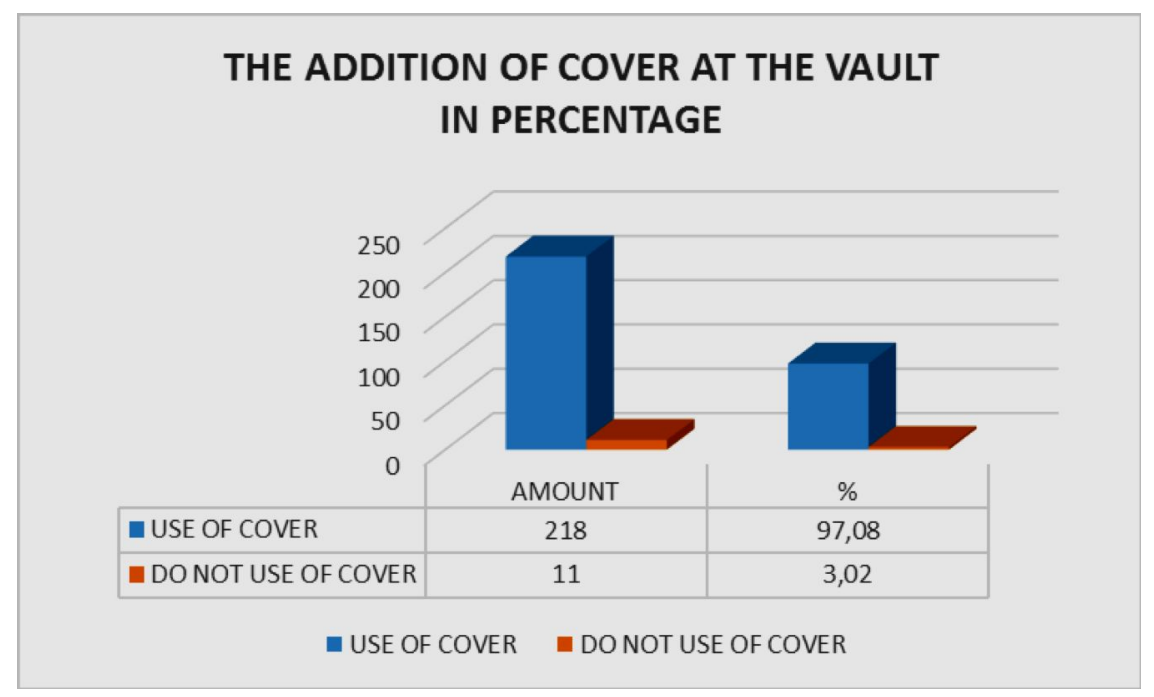

Figure 15. The Addition of Cover at the Vault in Percentage Source: Author's Analysis, 2017 
Table 1. The Relationship of Position of the Vault and Its Additional Functions

\begin{tabular}{ccccccc}
\hline $\begin{array}{c}\text { Position of the } \\
\text { Vault }\end{array}$ & Service & Relax & $\begin{array}{c}\text { Wdditional Functions of Vault } \\
\text { Welcoming }\end{array}$ & Cage & Work & Storage \\
\hline Full & 12 & 16 & 11 & - & - & 4 \\
Middle-Side & 19 & 18 & 10 & 19 & 20 & 16 \\
Back & 22 & 2 & - & 21 & 9 & 19 \\
Front & - & - & 7 & - & 4 & - \\
\hline
\end{tabular}

The various activities that occur in the vault is possible because the typical stilt houses in Pantai Bahari fishing village has $2.5 \mathrm{~m}$ height which allows human activities and needs for shelter. Furthermore, rapid development of the population and the increasing number of family members in a single unit house encourage the emergence of additional functions of the vault (Table 1).

Moreover, looking at the positions and functions, the community in Pantai Bahari fishing village also make some development and innovation on of the use of material to cover the vault. The material choices come in several types. Figure 16. in the following expose the material in use as the vault cover by the local people in percentage.

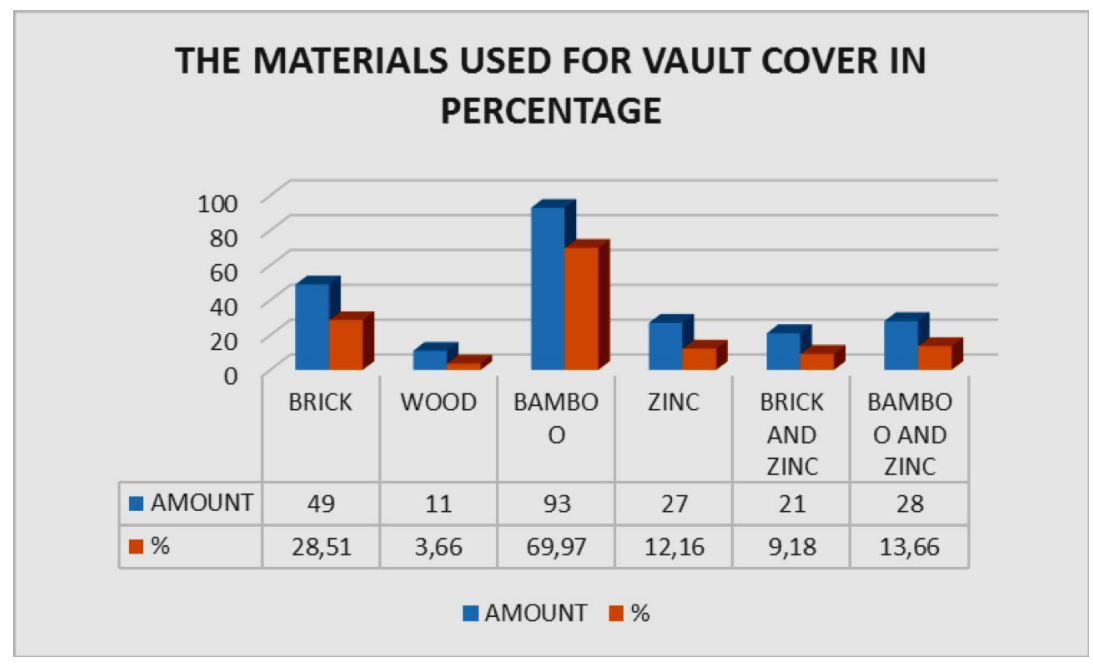

Figure 16. The Materials used for Vault Cover in Percentage Source: Author's Analysis, 2017

Figure 16 above displays the comparison and percentage of materials used to cover the vault in houses in Pantai Bahari fishing village. When analysed further, the material choice for the cover is adjusted to the additional functions of the vault. Here are some additional functions of the vault and the choice of cover materials (Table 2). 
Table 2. The Position of Vault and the Materials Used

\begin{tabular}{ccccccc}
\hline \multirow{2}{*}{$\begin{array}{c}\text { The Position of } \\
\text { Vault }\end{array}$} & Brick & Wood & Bamboo & Zinc & Brick+Zinc & Bamboo+Zinc \\
\hline Full & 24 & - & 3 & 7 & 6 & - \\
Side-Back & 13 & 2 & 31 & 9 & 7 & 7 \\
Back & 5 & 8 & 53 & 8 & 8 & 20 \\
Front & 7 & 2 & 6 & 3 & - & 1 \\
\hline
\end{tabular}

Based on the above data (Table 2), the choice of materials used for vault cover is related to the position of the vault and its additional functions. The main purposes of vault as a service area, warehouse and cage for cattle in Pantai Bahari are correlated with the findings of Altman and Chemers (1984) that stilt houses from natural materials usually use the vault to accommodate livestock, to store fishing and farming equipment, harvest, and so on.

\section{CONCLUSION}

Traditional Bugis Makassar houses are famous for its typical stilt houses that characterize Bugis Makassar culture. This type of house is commonly found in Pantai Bahari fishing village. Generally, the houses in the village represent the philosophy of the Underworld, the Middle world, and the Upper world.

As time goes by and there has been a growing need for space, the fisherman community in the village perform some improvement on their houses, as seen in the functions of porch and vault. High population and the increasing number of family members in a single unit house encourages the extended function of both porch and the vault as the people require wider space for accommodating the needs of the inhabitants. One alternative is to extend the space under the house or so-called the vault (Table 3 ).

Table 3. Conclusion on the Relationship of Additional Functions of Vault and the Use of Materials

\begin{tabular}{|c|c|c|c|}
\hline Function Room & & Material & Description \\
\hline Service & $\begin{array}{l}- \\
-\end{array}$ & $\begin{array}{l}\text { Wood } \\
\text { Bamboo }\end{array}$ & $\begin{array}{l}\text { Accommodating dish washing, } \\
\text { laundry, and house cleaning. It needs } \\
\text { ventilation to allow air circulation } \\
\text { while avoiding overheat. }\end{array}$ \\
\hline Rest & $\begin{array}{l}- \\
-\end{array}$ & $\begin{array}{l}\text { Bamboo } \\
\text { Brick }\end{array}$ & $\begin{array}{l}\text { Accommodating private activities } \\
\text { which require tight cover }\end{array}$ \\
\hline Guests receive & - & Brick & Accommodating semipublic activities \\
\hline
\end{tabular}




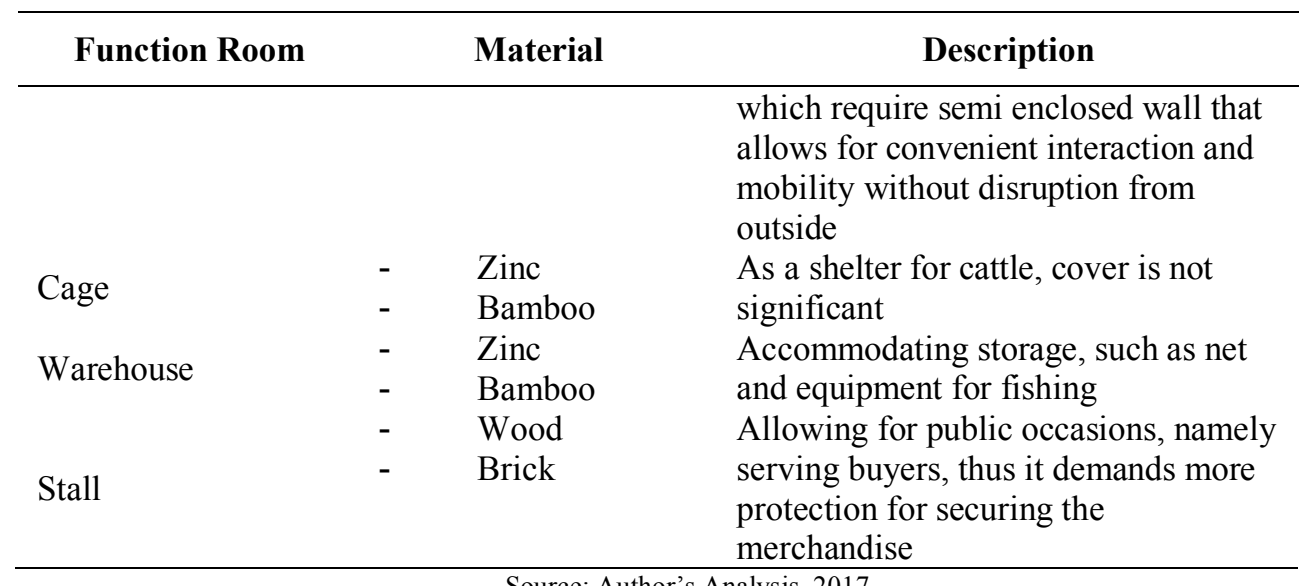

Figure 17 below shows the picture representing the condition of additional functions of vault and the use of materials for cover:
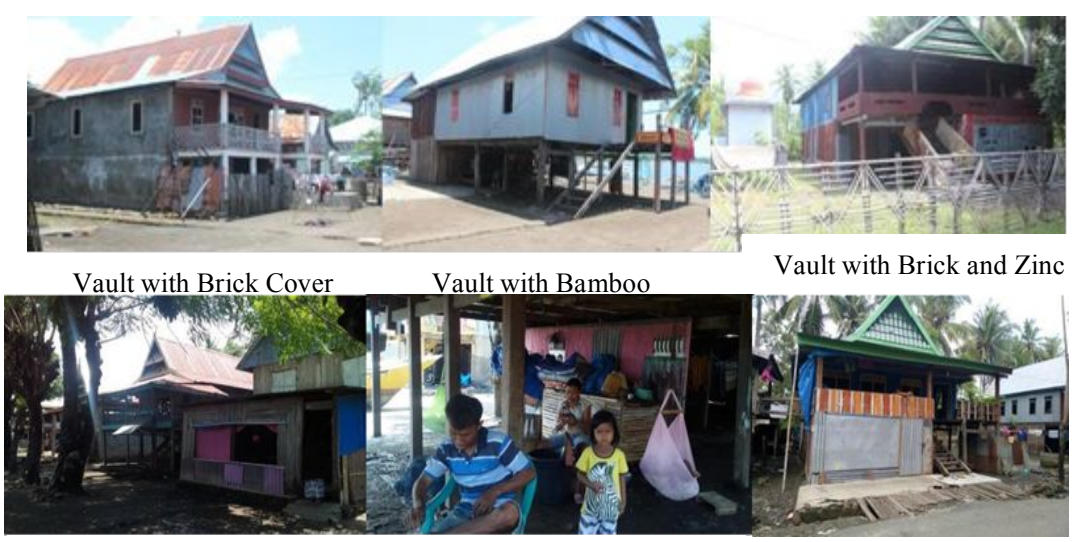

$$
\begin{aligned}
& \text { Vault with Brick and } \\
& \text { Wood Cover }
\end{aligned}
$$

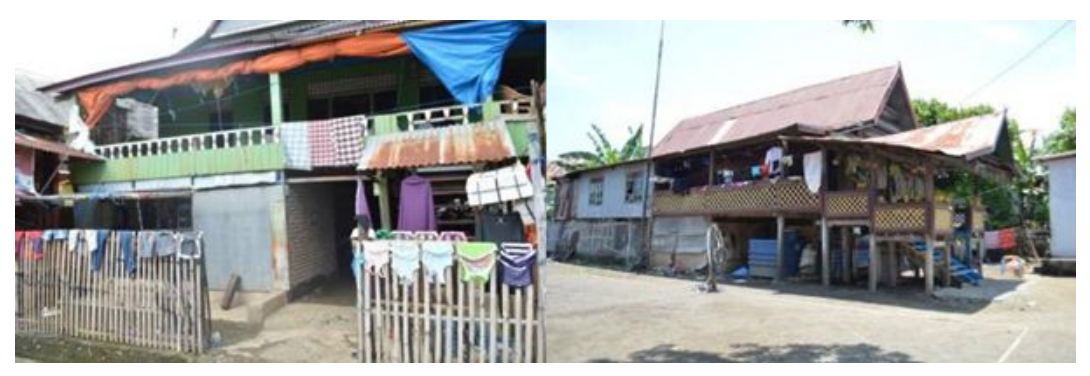

Vault with Brick and Zinc

Vault with Wood Cover Cover

Figure 17. The Additional Functions of the Vault and the Materials for Cover Source: Author's Analysis, 2017 


\section{REFERENCES}

Altman, I. and Chemers, M. (1984), Culture and Environment, Cambridge University Press, Engglewood Cliffs N.J., New York.

Data Y., (1977), Bentuk-Bentuk rumah Bugis Makassar, Penerbit Proyek Pengembangan Media kebudayaan direktorat Jenderal Kebudayaan. Dep. P dan K. RI., Makassar.

Budiharjo, E. (1983). Menuju Arsitektur Indonesia. Penerbit Alumni, Bandung.

Koentjaraningrat (1999), Manusia dan Kebudayaan di Indonesia, Djambatan, Jakarta.

Mangunwijaya (2009), Perubahan Bentuk dan Fungsi Arsitektur Tradisional Bugis di Kawasan Pesisir Kamal Muara, Jakarta Utara. Department of Architecture Gunadarma.

Mardanas, I. et al. (1985), Arsitektur Tradisional Daerah Sul-Sel, Dep. P dan K, Jakarta.

Mattulada. (1988), Sejarah Masyarakat dan Kebudayaan Sulawesi Selatan, Hasanuddin University Press, Ujung Pandang.

Tato, S. (2008), Arsitektur Tradisional Sulawesi Selatan dari Masa ke Masa, Seminar Regional Arsitektur Rumah dan Perumahan Tradisional di Kawasan Timur Indonesia, Jurusan Arsitektur Fakultas Teknik Unhas dan BPTPT Makassar.

http//www.GoogleEarth.Com (Accessed on 07 October 2017)

Field Survey (2017), Desa Nelayan Pantai Bahari Kecamatan Bangkala Kabupaten Jeneponto 